\title{
"La Philosophie n'est qu'une poësie sophistiquée": The Role of Metaphor in Montaigne's Essais
}

\author{
PAULA KOPPISCH
}

The exercitation Montaigne enjoyed in the act of reading is shared by readers of his own text in a variety of ways. Perhaps none is more engaging than the heightened awareness of language to which the text beckons us. When Sainte-Beuve declared that "pensée, image, chez lui, c'est tout un," ${ }^{1}$ he pinpointed an aspect of Montaigne's style that has continued to attract and exercer the word-conscious reader. By the dense, remarkably dexterous exercise of metaphor in the Essais, we are led to question the role of imagery in Montaigne's thought process and to elucidate the link, in as much as it can be articulated, between conception and expression. ${ }^{2}$ Although Montaigne is critical of superficial concerns with language, he gives serious consideration to questions of effectiveness in expression, and, at a more elemental level, to questions about the way we arrive at the conceptions we seek to express. These concerns are intimately connected; by bringing them together, we begin to grasp what is really contained in Sainte-Beuve's apt description of Montaigne's style.

$$
\text { * * * }
$$

Montaigne is always wary of the exaggerated attention given to the forms of language by grammarians and rhetoricians and frequently condemns it outright. Primarily attentive to the substance of expression - in those he reads as well as in his own communications - he derides the laborious attempts of scholars to call words by other words, since the new term does nothing to advance our understanding of the original utterance. "Oyez dire metonomie, metaphore, allegorie et autres tels noms de la grammaire, semble-t-il pas qu'on signifie quelque forme de langage rare et pellegrin? Ce sont titres qui touchent le babil de vostre chambriere" (I:51, 294b). ${ }^{3}$ The enormous proliferation of works on language, from Dindyme's six thousand volumes on the subject of grammar alone to the escrivaillerie of his own time (III:9, 923b), incites Montaigne to wish that the disciples of Pythagoras had taken more literally his counsel to maintain a silence of two years. 


\section{0 / Renaissance and Reformation}

If treatises on grammar appear futile and superfluous to Montaigne, the business of rhetoricians provokes in him an even stronger reaction. At worst, grammarians waste our time by diverting our attention from more serious pursuits, but rhetoricians risk doing us genuine harm. All too frequently, the "art of speaking and writing well" can be translated as the "art of deception through words." Montaigne recalls the phrase of a rhetorician of times past who described his trade as "de choses petites les faire paroistre et trouver grandes" (I:51, 292a), adding that "Ariston definit sagement la rhetorique: science à persuader le peuple; Socrates, Platon, art de tromper et de flatter; et ceux qui le nient en la generale description le verifient partout en leurs preceptes" (293c). ${ }^{4}$ Applying rhetorical devices to speech is much like putting makeup on a woman's face. Montaigne pursues this analogy to emphasize the more dangerous consequences of verbal adornment: while fard tricks only our eyes, rhetorical devices work to deceive our judgement - "et d'abastardir et corrompre l'essence des choses" (292a). Such willful deception in the use of words runs directly counter to Montaigne's own preoccupations with language and its relationship to truth. The right use of words is the communication of truth; its corruption, the lie, is "un maudit vice. Nous ne sommes hommes et ne nous tenons les uns aux autres que par la parole" (I:9, 37c).

When rhetoric is employed, not to deceive, but merely to add lustre to expression, it still arouses Montaigne's disapproval. "L'éloquence faict injure aux choses, qui nous destourne à soy" (I:26, 171c). Words which draw attention to themselves rather than serve the needs of thought and communication are usually characteristic of a mind devoid of actual substance. Just as with affectations of dress or mannerism, "c'est pusillanimité de se vouloir marquer par quelque façon particuliere et inusitée" in the realm of language (172c). The quest for original turns of expression and rare words is the mark "d'une ambition puerile et pedantesque" (172c). Montaigne would much rather err in the opposite sense and leave an impression of nonchalance, even neglect, in his use of language. The words he finds most apt for expressing his thoughts are "ceux qui servent aux hales à Paris" (172c).

Montaigne discusses at length his preferences as a reader in the essay "Des livres" (II:10). His quest for a broader and at the same time more penetrating understanding of men is nourished by historians and by the moralists, Plutarch and Seneca. But Cicero, who would also be likely to feed his interest in moral philosophy, meets with resistance: "à confesser hardiment la verité...sa façon d'escrire me semble ennuyeuse,... .ce qu'il y a de vif et de mouelle, est estouffé par ses longueries d'apprets. . la plus part du temps je n'y treuve que du vent" (393a). Nonetheless, Montaigne's rejection of "le pere de l'eloquence Romaine" (390c) for a style inappropriate to the matter being treated is neither a 
condemnation of style in language nor a plea for an absence of style. Certain writers, especially certain poets, appeal to him precisely for their graceful and individualized handling of language. It is for reasons of style that Montaigne admires the poetry of Virgil, Lucretius, Catullus and Horace. Prizing style that is one with the substance of poetry, the essayist finds that the merit of these poets lies in their having avoided " 1 'affectation et la recherche, non seulement des fantastiques elevations Espagnoles et Petrarchistes, mais des pointes mesmes plus douces et plus retenues, qui font l'ornement de tous les ouvrages Poëtiques des siècles suyvans" (391a). In a later essay (III:5), speaking of Virgil in particular, Montaigne exposes what for him is the real source of the poet's art. The vividness, the depth, the vigour of Virgil's expression issue from the quality of his mind - “je ne dicts pas que c'est bien dire, je dicts que c'est bien penser. C'est la gaillardise de l'imagination qui esleve et enfle les parolles" (850-851b). Style - the figures of speech, the choice of vocabulary, the shapes of sentences - has its origin in the mind conceiving, not in a superimposed quest for originality. A mind which conceives simply will speak simply; another seeing "plus cler et plus outre dans la chose" will demand an expression "outre l'ordinaire" (851b). When it is meaning which seeks out and produces expression, the resultant style is "non plus de vent, ains de chair et d'os" (ibid.).

The word, consubstantiel with idea, is the expression Montaigne strives to achieve in the Essais. He uses, for this purpose, the potentially rich resources of his native tongue. In the sixteenth century, the French language was approaching a maturity and fullness which would permit the production of a literature in the vernacular worthy of comparison to the masterpieces of the ancients. Already Montaigne recognizes that "Ronsard et du Bellay ont donné credit à nostre poësie Françoise" (I:26, 170a), and he finds them "guieres esloignez de la perfection ancienne" (II:17, 645a). Surely his choice to write in French was made not only because he was writing "à peu d'hommes et à peu d'années" as he tells us (III:9, 960c), but also out of a desire to "illustrate" the French language, in the spirit of Du Bellay's Deffence. The gifted writer, whom Montaigne finds a rarity among "tant d'escrivains françois de ce siecle" (III:5, 851b), expands and enriches the possibilities of his idiom:

Le maniement et emploite des beaux espris donne pris à la langue, non pas l'innovant tant comme la remplissant de plus vigoreux et divers services, l'estirant et ployant. Ils n'y aportent point des mots, mais ils enrichissent les leurs, appesantissent et enfoncent leur signification et leur usage, luy aprenent des mouvements inaccoustumés, mais prudemment et ingenieusement (ibid.).

Though not partisan to the Pléiade's theoretical programme to enrich the French language through the introduction of neologisms, archaisms 
and the stylistic imitation of Latin and Greek authors, Montaigne does recognize with them ample room for development within the domain of terms already comprising the French language:

En nostre langage je trouve assez d'estoffe, mais un peu faute de façon; car il n'est rien qu'on ne fit du jargon de nos chasses et de nostre guerre, qui est un genereux terrein à emprunter; et les formes de parler, comme les herbes, s'amendent et fortifient en les transplantant. Je le trouve suffisamment abondant, mais non pas (c) maniant et (b) vigoureux suffisamment. Il succombe ordinairement à une puissante conception (851-852b).

This very resistance of French in its ordinary usage to the expression of "une puissante conception" nurtures the imaginative writer's inclination toward metaphor. When words in their literal sense fail to accommodate a nascent idea, the intervention of metaphor gives rise to the formulation of what might otherwise remain inexpressible or unexpressed. As a reader, Montaigne is sensitive to the beauty and energy of metaphor, even when frequency and usage have dulled their original freshness "cela n'oste rien du goust à ceux qui ont bon nez" (852b). As much as he scorns the affected and purely decorative in the use of metaphor, he has a perspicacious appreciation for metaphor used well. Not unaware of the density of imagery in his own handling of language - he had been told he was "trop espais en figures" (853b) - Montaigne finds expression through metaphor natural to his way of thinking and speaking. "Est-ce pas ainsi que je parle par tout? me represente-je pas vivement? suffit! J'ay faict ce que j'ay voulu: tout le monde me reconnoit en mon livre, et mon livre en moy" (ibid.).

Montaigne's recurrent statement of the naturalness and integrity of his expression in the Essais has met with varying degrees of acceptance among his critics. ${ }^{6}$ One can easily recognize that the seemingly artless, conversational tone he achieved in his writing did not come without some conscious effort. And he himself remarks "qu'à force de vouloir eviter l'art et l'affectation, j'y retombe d'une autre part" (II:17, 621a). Above all Montaigne wants to escape the label of "professional writer," so he shuns any resemblance to those with pedantic or literary pretensions (II:37, 764a). However, were he to be of the métier, he would seek to naturalize art as others have "artified" nature (III:5, 852c). His insistence that the "fin principale et perfection" to which he seeks to bring the Essais "c'est d'estre exactement [sien]" (853b), raises the question of how metaphor functions in so deliberately natural an expression.

Floyd Gray has observed that "le vocabulaire de Montaigne est déterminé par sa méfiance vis-à-vis du mot abstrait, du mot vide. 
S'il emploie une expression abstraite, il juxtapose en même temps une expression concrète qui l'explique, qui le rend sensible."7 Montaigne's avoidance of the abstract and cultivation of the palpable in expression are intimately related to the way in which he perceives the mind to operate. Abstract concepts do not exist independently, but have their origin in concrete experience. In his critique of reason in the "Apologie," Montaigne begins with the epistemological premise that "toute cognoissance s'achemine en nous par les sens: ce sont nos maistres ... (a) La science commence par eux et se resout en eux" (II: 12, 572a). As the mind moves in the direction of abstractions, it distances itself from the source of its conceptions and runs the risk of erring in the empty structures of its own creation. It is always to experience, to a concrete foundation, that Montaigne looks for his grasp of truth. The mind must not be disassociated from the body, but directed toward maintaining their natural cooperation and mutual dependency. "A quoy faire desmembrons nous en divorce un bastiment tissu d'une si joincte et fraternelle correspondance? Au rebours, renouons le par mutuels offices. Que l'esprit esveille et vivifie la pesanteur du corps, le corps arreste la legereté de l'esprit et la fixe" (III:13, 1094-95b). For language most effectively to embody thought grounded in experience, it should have continual recourse to the source of the conceptual process by integrating abstractions with their sensual correlatives. Montaigne's use of metaphor illustrates this perpetual interaction of the mind with bodily experience and his keen awareness that "c'est tousjours à l'homme que nous avons affaire, duquel la condition est merveilleusement corporelle" (III:8, 909b).

With the development of Montaigne's arguments against reason in the "Apologie," however, the senses too are shown to be unreliable indicators of truth. Sense perceptions are subject to distortion because of the perspective imposed by distance (II:12,576-577a) or to a defect in the sense organs themselves. And there is also the problem as to whether man's five senses are adequate to the perception of phenomena in their completeness. Do not certain animals get along quite satisfactorily without all the senses we happen to enjoy (572-573a)? There is really no way of knowing whether there exist more senses than those we experience for "c'est le privilege des sens d'estre l'extreme borne de nostre apercevance; il n'y a rien au delà d'eux qui nous puisse servir à les descouvrir; voire ny l'un sens n'en peut descouvrir l'autre" (ibid.). One cannot speak to a man blind from birth in images of light, for nothing in his experience can utilize such images. Montaigne relates an example of a blind man who had imitatively adopted the speech patterns of seeing people, though he had no experience of vision. The same man even participated in the sports of hunting and tennis without being able to see the rabbit 
or the ball at which he foolishly, though unknowingly so, took aim. From this concrete anecdote, Montaigne draws an analogy to the way men reason and speak about matters beyond the realm of their limited possibilities of certitude: "Que sçait-on si le genre humain faict une sottise pareille, à faute de quelque sens, et que par ce defaut la plus part du visage des choses nous soit caché?" (574a). The presumptuous assertions and debates among philosophers and theologians are ventures into matters about which we cannot produce positive verification; ultimately we must admit to our "necessaire bestise" (576c). In Montaigne's own use of language, in his marked preference for concrete terms over abstractions, he avoids making pretentious claims to knowledge beyond his grasp by virtue of the metaphorical dimension so elemental to his expression.

Contemporary philosophers of language continue to explore the role of metaphor in conceptualization and expression. Owen Thomas observes that "only man can make statements which are, strictly speaking, not true" and that "paradoxically, the ability to make such statements - the ability to formulate metaphors - is sometimes necessary to the comprehension of ideas and almost invariably underlies the perception of beauty, not only in literature but also in history, philosophy and the sciences."

However, metaphorical language is often employed and understood in an almost, if not completely literal sense. Colin Murray Turbayne investigates the mistaken use of metaphor involving the presentation of the "facts of one sort in the idiom of another without awareness. . .to do this is not just to fuse two different senses of a sign; it is to confuse them."9 Turbayne finds such confusion in certain models of presentday science just as Montaigne did in the theological and philosophical models used to explain God, nature or the soul - "Et certes la philosophie n'est qu'une poësie sophistiquée" (II:12, 518c). Those lured into believing in the "myths of metaphor" presume to know the essence of things, forgetting they are only dealing with images of essence.

Renaissance writers, in quest of a unified conception of the world, frequently regarded the image as an "instrument de connaissance." 10 But Montaigne maintains that "nous n'avons aucune communication à l'estre" (586a), and, in his usage, rejects any rigidly didactic role in metaphor. His own images are mobile, open, changing - in harmony with his vision of a world qui branle sans cesse. Michaël Baraz describes the metamorphosing character of Montaigne's images:

Chaque chose peut être rapprochée de n'importe quelle autre....Pas de termes de comparaison privilégiés; ainsi l'âme revêt tantôt l'apparence physique d'une personne ... tantôt elle apparaît comme un objet inanimé. . et aucune de ces figures ne prétend nous révéler la nature cachée de l'âme. ${ }^{11}$ 
Not mistaking the image for the thing to which it relates, Montaigne uses imagery to communicate his vision of the world as an organic, harmonious cosmos, of which man is a part, but of which he possesses no comprehensive, fixed and closed knowledge.

While man might not have certain knowledge of the world, he does have experience of it. An image gives expression to the unknown in terms of the known, and most especially in terms of what is most immediate to our experience, the senses. Through the senses, we perceive not only the phenomena proper to the operation of each sense taken individually, but also the numerous collective impressions derived from comparing one sense to another: "combien d'argumens, de consequences et de conclusions tirons nous aux autres choses par la comparaison de l'un sens à l'autre!'"(575a). Lest this comparative perception be confused with direct sensual experience, Montaigne admonishes, "Nous avons formé une verité par la consultation et concurrence de nos cinq sens; mais à l'advanture falloit-il l'accord de huict ou de dix sens et leur contribution pour l'appercevoir certainement et en son essence" (ibid.). Throughout the "Apologie," the emphasis is on the insufficiency of man's powers of apprehension, for the essay is intended to combat the arrogance of man's reason. But men have always made and will undoubtedly continue to make claims to truth and to wage battles over differences arising from the values they pretentiously assign to their words. Witness to numerous legal and theological conflicts in his day, Montaigne declares, "Nostre contestation est verbale. . . La question est de parolles, et se paye de mesme" (III:13, 1046b). What is needed is a realistic evaluation of the comparative process through which ideas, issuing from a wide diversity of experience, come to be formulated.

Montaigne does not hesitate to make the comparisons through which his ideas take on form. His concern for a style that is one with thought - bien dire meaning bien penser - demands that the joining of terms in metaphor be a tightly conceived one. At the same time, he clearly recognizes the separation between words and what they are intended to represent: "Il y a le nom et la chose; le nom, c'est une voix qui remerque et signifie la chose; le nom, ce n'est pas une partie de la chose ny de la substance, c'est une piece estrangere joincte à la chose, et hors d'elle" (II:16, 601a). This sensitivity to the distance between words and their referents is basic to the use of metaphor with awareness. Just as a sign is not identical to the thing expressed, the substitution in metaphor of one sign for another (or of the attributes of one sign for those of another) is an elected, rather than necessary expression of the thing signified. Metaphor is more than a process of simple substitution, however. The metaphorical concept is generated through the operation 


\section{6 / Renaissance and Reformation}

of semantic motion giving us two ideas which "co-operate in an inclusive meaning." 12 The interaction between terms is determined by a relationship already existing or perhaps being posited between the two terms. Montaigne's metaphors issue from the traditional grounds in resemblance. Possessing what Aristotle calls "an eye for resemblances," 13 Montaigne judiciously assesses the positive and negative aspects of the comparative process:

Comme nul evenement et nulle forme ressemble entierement à une autre, aussi ne differe nulle de l'autre entierement... . Toutes choses se tiennent par quelque similitude, tout exemple cloche, et la relation qui se tire de l'experience est tousjours defaillante et imparfaicte; on joinct toutesfois les comparaisons par quelque coin (III:13, 1047b).

Comparisons must not be construed into identities, yet by making analogies, by joining differing perceptions and varying experiences in the bonds of metaphor, we can give expression to our conceptions of reality, as approximate as they might be. Our associations remain faulty and imperfect, for every example limps. Nevertheless, there are similarities to be perceived and so our comparisons are not completely erroneous or unwarranted. Unlike the extreme skeptics who hold that nothing can be known or stated about anything at all, Montaigne manages to deal with knowledge which is of necessity relative and to give expression to his relative experience. The metaphorical density of his language is central to his conceptual process and his belief that "nostre estat accommodant les choses à soy et les transformant selon soy, nous ne sçavons plus quelles sont les choses en verité" (II:12, 584a).

$* \quad * \quad *$

Language for Montaigne is a tool that can be used badly or well. Rhetoricians and affected poets use it to deceive or to affect a studied and empty elegance. The gifted poet, inspired by a "divine fury," wields language so as to "transpercer et transporter" (I:37, 228c). Montaigne himself experienced such effects in poetic language from his earliest encounters with reading. He fully understands that poetry does not work to persuade our judgement; rather, "elle le ravit et ravage" (ibid.). Too often, the prose writer, using the images of poetry for purposes of persuasion, falls into the mistaken use of metaphor, what Philip P. Hallie calls the language of the Assertive imagination. ${ }^{14}$ Underlying Montaigne's use of poetic language is an awareness of the distance between words and what they are intended to represent and the distance between our conceptions of things and the way things actually are. Opposed to these distances is the closeness Montaigne values between thought and expression. A tension is set up in the 
contradictory limitations and aspirations Montaigne assigns to language. This tension is at the very core of the metaphorical process, energizing the semantic motion at work in metaphor. The successful metaphor, emanating from bien penser, brings together two signs and their attributes, joining them "par quelque coin," so as to produce an image which faithfully incarnates the conception the mind has of a given thing. As Montaigne's primary concern with language is that it provide effective communication, he needs no more than the common words "qui servent aux hales à Paris," but these he "bends," "transplants" and "stretches" to shape the conceptions of his ceaselessly energetic mind. Metaphor enables Montaigne to render his fantaisies, the chimeres of his imagination, and the solid prises of his judgement "intellectuellement sensibles, sensiblement intellectuels" (III:13, 1087c). From his words, "non de vent ains de chair et d'os," comes into being the "livre consubstantiel à son autheur" (II:18, 648c).

Michigan State University

Notes

1 Port Royal, III, 3 (Paris: Gallimard, 1953), 864.

2 The question of the anteriority of thought to language in Montaigne is examined by HélèneHedy Ehrlich, Montaigne: la critique et le language (Paris: Editions Klincksieck, 1972), pp. 70-90; and by Dilys Winegrad, "Language as Theme and Image in the Essais of Mon taigne," Symposium 28, 3 (1974), 274-83.

3 Michel de Montaigne, OEuvres complètes, ed. Albert Thibaudet and Maurice Rat (Paris: Gallimard, 1967). All references to the text of the Essais are made to this edition and are identified by book, chapter, page and strata in parentheses.

4 Emphasis added.

5 Emphasis added.

6 Barbara Bowen presents her views on this issue and summarizes those of a number of other critics in The Age of Bluff: Paradox and Ambiguity in Rabelais and Montaigne (Urbana: The University of Illinois Press, 1972), p. 114.

7 Le Style de Montaigne (Paris: Nizet, 1958), p. 41.

8 Metaphor and Related Subjects (New York: Random House, 1969), pp. 3-4.

9 Myth of Metaphor (Columbia: University of South Carolina Press, 1970), p. 22.

10 Michaël Baraz, L'Etre et la connaissance selon Montaigne (Paris: Librairie José Corti, 1968), p. 61.

11 Ibid., p. 63

12 I.A. Richards, The Philosophy of Rhetoric (New York: Oxford University Press, 1965), p. 119.

13 On the Art of Poetry with a Supplement on Music, trans. S.H. Butcher, The Library of Liberal Arts (New York: The Bobbs-Merrill Company, Inc.), XXI, p. 28.

14 Hallie explains that the use of the Assertive imagination "involves us in inferences from our images to facts or statements beyond those images." The Scar of Montaigne: An Essay in Personal Philosophy (Middletown: Wesleyan University Press, 1966), p. 77. 